\title{
A quantitative assessment of students' experiences of studying music: a Spanish perspective on the European credit transfer system (ECTS)
}

\author{
José-María Esteve-Faubel ${ }^{1}$, Jonathan Stephens ${ }^{2}$ and \\ Miguel Ángel Molina Valero ${ }^{1}$
}

${ }^{1}$ Faculty of Education, University of Alicante, Carretera San Vicente del Raspeig s/n - 03690 San Vicente del Raspeig, Spain

${ }^{2}$ Department of Music School of Education, University of Aberdeen, MacRobert Building King's College, Aberdeen AB24 5UA, UK

jm.esteve@ua.es, j.p.stephens@abdn.ac.uk,ma.molina@ua.es

The purpose of this investigation is to evaluate whether or not the allocation of time proposed in the Music Study Guide, adapted from the European Higher Education Area (EHEA) guidelines, is consistent and adequate for students with minimal musical knowledge. The report takes into account the importance of students' previous knowledge and the relation this has to the time and effort expended by students in acquiring appropriate knowledge and skills. This is related also to the adequacy of the course specification to meet the demands of university study and the labour market. Results show that those students who enrolled at university without any previous musical knowledge are likely to experience significant difficulty in the acquisition of certain musical and professional competences. This highlights a need to reinforce the music curriculum, or establish zero-level courses, in order to enable such students to succeed in the subject.

\section{Introduction}

As is the case in other areas of social life, Europe is currently immersed in the process of harmonising its university system to ensure an equivalent level of education to all students in its member states. This European Higher Education Area provides for a common system of credits - the European Credit Transfer System - which enables the equivalence of degrees obtained in different countries and encourages the mobility of undergraduates and graduates.

Like the rest of Higher Education curricular areas, music education takes the Bologna Declaration as its reference framework. The Bologna declaration on convergence within university education in Europe, which was signed in 1999 and ratified at the Berlin conference (2003), sets out the commitment to coordinate education policies with the aim of providing a single European Higher Education Area by 2010. 
Music education professionals should exploit this window of opportunity to move towards this academic area in the field of higher music education. At this initial stage, student opinions regarding the time and effort required to successfully complete music studies under the current education system can help align teaching strategies and adapt the study programmes to the new European system.

The main purpose of the Bologna plan is to increase the mobility and employability of European university graduates, thereby building a knowledge-based Europe and ensuring the international competitiveness of higher education in Europe (Reichert \& Tauch, 2003). These principles (Kelly, 2003) suggest the need to guarantee the quality of higher school education and to identify comparable criteria and methodologies across the whole of Europe. This is, without doubt, a very complex issue (Jacobs \& Van Der Ploeg, 2006a, 2006b) since it requires harmonisation of a great diversity of higher education systems, taking into account cultural and linguistic pluralism. Moreover, it needs keeping up with the constantly changing needs and expectations of society as well as with the development of scientific knowledge.

In the framework of the Socrates programme - recently replaced by the Lifelong Learning Programme 2007-2013 (http://ec.europa.eu/education/lifelong-learningprogramme/doc78_en.htm) - the European Commission launched the Tuning Educational Structures in Europe Project (González \& Wagenaar, 2003) in order to determine and establish the generic and specific competencies of each degree.

This has led to an academic framework involving, on the one hand, the adoption of a common system of university degrees that has two levels (undergraduate and postgraduate) to improve the integration and recognition of diplomas and, on the other hand, the accepting of the so-called European Credit Transfer and Accumulation System as a benchmark designed to structure and organise education.

It should be noted that the transposition of all the postulates conceived within this framework to the primary teaching degree has translated into the development of a structure grouped in three formative blocks - core subjects, teaching and learning disciplinary subjects and work experience. These are further subdivided into 10 modules and a final project (Table 1).

In addition, an optional subject worth 30 credits can be taken which, as is the case with the Music Mention in Spain, gives students the opportunity to become specialists in this subject area.

This enables primary education undergraduates to obtain a special mention, which will appear on the Diploma Supplement. This mention does not have any professional purpose. Neither does it imply any difference in the acquisition of the basic skills, the teaching and learning disciplinary skills, the practical or transversal skills. It solely reflects the intensification pathway chosen by students, in this particular case in music, on the basis of their personal preferences.

It should be noted that European Credit Transfer System is essential for the correct implementation of the suggested teaching-learning process as it is a tool for measuring learning outcomes. It represents the student workload required to achieve the objectives of the study programme-teaching guide (Reichert \& Tauch, 2005). This unit of measurement includes theoretical and practical skills, as well as other guided academic activities theoretical or practical contact hours, study hours, attendance of seminars, writing of 
Table 1 Structure of the primary teaching degree following Bologna regulations

\begin{tabular}{ll}
\hline \hline & Module \\
\hline Core subjects & Learning and personality development \\
& Educational processes and contexts \\
& Society, family and school \\
Teaching and learning disciplinary subjects & Experimental sciences \\
& Social sciences \\
& Mathematics \\
& Language \\
& Musical and artistic education \\
& Physical education \\
Work experience & Teaching experience \\
Final project & Final project \\
\hline \hline
\end{tabular}

essays or reports, work experience or projects, the hours required for the preparation of examinations and tests - including the amount of further independent work (Winne, 1997) required to achieve a given set of learning outcomes in each of the subject areas of the teaching guide (O'Neill et al., 2005).

The subject area targeted in this study (Esteve Faubel et al., 2006, p. 143) has been divided into three modules: Sound. Pitch - I; Sound. Duration and notation - II; Introduction and presentation of interpretative concepts and planning of musical language related activities. Music improvisation and composition - III. The organisation of the learning activities is as follows:

Lecture sessions ( 1.2 credits $=30$ hours): Introduction and presentation of the module concepts.

Exercise classes ( 1.4 credits $=35$ hours): Classroom based practical exercises focusing on the module items.

Field classes ( 1.6 credits $=40$ hours): Localisation and study of the main documentary sources and the structuring of the module resources.

Organised tutoring sessions ( 0.4 credits $=10$ hours). Critical reading and discussion of module-based texts.

Final project ( 1.4 credits $=35$ hours): Analysis, presentation and interpretation of case studies relating to the respective module.

This is illustrated in Table 2. It is worth noting that the entire programme should be delivered during one semester and 1 European Credit Transfer System credit is equal to 25 hours of student work.

The European Credit Transfer System is a system based on the student workload required to achieve a given set of learning outcomes. Credits in the European Credit Transfer System express what the student will know, understand or be able to do after successful completion of a process of learning. They are linked to the academic level descriptors within the qualifications frameworks.

\section{CAMBRIDGE JOURNALS}


Table 2 Organisation of learning activities in musical language course

\begin{tabular}{lllll}
\hline \hline & Module I & Module II & Module III & Total \\
\hline Lecture sessions & 0.5 & 0.5 & 0.2 & 1.2 \\
Exercise classes & 0.6 & 0.6 & 0.2 & 1.4 \\
Field classes & 0.3 & 0.3 & 1 & 1.6 \\
Tutoring sessions & 0.1 & 0.1 & 0.2 & 0.4 \\
Final project & 0.2 & 0.2 & 1 & 1.4 \\
Total & 1.7 & 1.7 & 2.6 & 6.0 \\
\hline \hline
\end{tabular}

The workload expresses the time and effort required by students to carry out all of the learning activities - classes, seminars, projects, practical work, autonomous learning and exams - to achieve the desired learning outcomes.

This new concept of education implies a definitive shift from teacher-focused learning strategies (Harden \& Crosby, 2000, p. 335) to student-centred learning (Kirsti \& Kirsi, 1995; Hall \& Saunders, 1997) in all countries involved in the process (http://www.ond.vlaanderen.be/hogeronderwijs/bologna/). The main principles of the student-centred approach are:

1. the reliance on active rather than passive learning,

2. an emphasis on deep learning and understanding,

3. increased responsibility and accountability on the part of the student,

4. an increased sense of autonomy in the learner,

5. an interdependence between teacher and learner,

6. mutual respect within the learner-teacher relationship,

7. and a reflexive approach to the teaching and learning process on the part of both teacher and learner. (Lea et al., 2003, p. 332)

Therefore, whether students take the special music mention or not, they should all receive basic music training enabling them to satisfactorily perform their teaching tasks in the primary classroom. As shown in the outline provided above, this subject area is part of the Musical and Artistic Education module.

Basic music training requires that students at least know how to read and write about the subject they intend to teach. In other words, on the one hand they should master the theoretical-practical study of music notation as well as intonation techniques. On the other hand they should know how to perform music - solfège - and they should be able, insofar as time permits, to experience music improvisation and composition among other things.

During the academic year 2003/2004 a teaching guide was designed by music teachers from the University of Alicante and the Autonomous University of Madrid (Esteve Faubel et al., 2006) in order to address these postulates.

The guide (Brandes \& Ginnis, 1996; Koper \& Olivier, 2004) provides answers to questions such as 'what is to be learnt, how and when it is to be learnt, with what outcome, what criteria and standards are to be used, how the judgements are made and by whom these judgements are made' (Gibbs, 1995, p. 1). With the guide in place, what needs to be assessed now is the effort and the time students need to put in to achieve the objectives, 
cover the contents, acquire the skills and competencies required to master the subject from the perspective of European Credit Transfer System. To this end, it is not enough just to implement the teaching guide. It also needs to be assessed from the students' perspective as they are at the heart of the new educational concept that lies at the basis of the teachinglearning process at university.

It is essential to determine how this shift in educational strategies affects student performance in higher education and, more specifically, in music. Whereas in other subject areas graduates receive basic training, many primary school trainees lack sufficient depth of musical knowledge (Alonso Marín, 2004; Esteve Faubel et al., 2006, 2009) and could therefore question the proposed educational approach.

Despite the importance of the proposed change in education in the European Union (Declaration of Bologna, 1999; Declaration of Prague, 2001; Declaration of Berlin, 2003; Declaration of Bergen, 2005), there are no studies that measure the time and effort future primary teachers in the European Higher Education Area need in order to master the musical content.

This requires an investigation into the background to the issue raised in this study, i.e. all points that address student performance in secondary and higher education in general or specific terms. Although some of these points may not be directly related to the European Credit Transfer System, they still provide information that can in practice be used in this study.

A systematic search was carried out to identify investigations related to the determinants of academic performance and the determinants of undergraduate grades. The following databases were consulted: Social Sciences and Humanities (ISOC), Education Resources Information Center (ERIC), Periodicals Index Online (PIO), PsycINFO, ProQuest and Google Scholar. A total of 120 articles were found from 1995 to 2010, some of which could serve as a basis for this study. However, there is surprisingly little literature available on this topic. Most of the 120 studies are directly rooted in a constructivist view of learning - activity, discovery and independent learning (Carlile \& Jordan, 2005).

A second search using the keywords 'useful resources and reading material for the European Qualifications Frameworks, Learning Outcomes and labels for European Credit Transfer System and Diploma Supplement, Structure of Higher Education', resulted in 43 articles corresponding to conference papers e.g. Bologna Seminar: The Scottish Experience (2008) Conference Paper by Heriot-Watt University, Edinburgh; UK Bologna Seminar on Learning Outcomes (2004): Using Learning Outcomes, Edinburgh, 1-2 July 2004 http://www.aic.Iv/ace/ace_disk/Bologna/Bol_semin/Edinburgh/index.htm; Conference Paper by Heriot-Watt University; European Consortium for Accreditation [ECA] 2007 International Conference on Learning Outcomes, Defining and Measuring Learning Outcomes in Higher Education, Zurich, 3-4 September 2007: http://www.oaq.ch/pub/en/Conference_LO.php; Council of Europe (2007) Forum on Qualifications Frameworks, Strasbourg. http://www.coe.int/t/dg4/highereducation/QF/; European Commission (2006-2007) Focus on the Structure of Higher Education in Europe 2006-2007 National Trends in the Bologna Process, Eurydice: http://www.dcu.ie/afi/docs/bologna/focus_on_the_structure_of_higher_ed.pdf, etc.

The analysis of all this documentation reveals that it is hard to identify a single model applicable to music education for primary school trainees and capable of systematising the

\section{CAMBRIDGE JDURNALS}


factors under investigation in all of these studies. That is because the determinants of student performance are difficult to define. Moreover, it is very difficult to ascribe distinguishable effects to each of the variables.

Nevertheless, all studies agree on three points: the factors that account for academic achievement or failure are inherent to the student, to the teacher and to the educational institution. These determinants are at the core of the proposed change in the European Higher Education Area.

Following this type of analysis of variables it can be assumed that workload, i.e. time and effort employed by students to study and assimilate a subject as part of their academic performance, is affected by different factors, including previous knowledge and/or studies.

Performance at university is directly related to performance in secondary education. The fact that performance improves when there is less of a time gap between a student finishing school and entering university offers a good measure of likely success at university (Tejedor Tejedor \& Caride Gómez, 1988; House et al., 1996; Sánchez Gómez, 1996; Betts \& Morell, 1999; Cohn et al., 2004).

Everything that has been said so far highlights the need to harmonise the European Higher Education Area on the one hand and, once achieved at a theoretical and administrative level, translate this into an educational reality - a Teaching Guide - in accordance with the guidelines set out in the Bologna Declaration.

With regards to music education, the analysis of the various curricula of the European Union member states not only reveals that the music training received by future primary teachers differs considerably from country to country, but also that students' initial knowledge when enrolling at university ranges from practically nonexistent to a mediumhigh level as instrumentalists.

Studies identifying the best predictors of students' academic success in a subject field show that performance at university is linked to the training received at secondary school in that particular area.

Therefore, the hypothesis put forward in this study is that if primary school students enrol at university without solid previous music training, the number of European Credit Transfer System credits assigned to a course unit is insufficient to achieve the desired learning outcomes for that unit.

This previous music training should at least enable students to read music, to sing in key with correction, and to play a melodic and/or harmonic instrument at an elementary and/or medium level.

As for the learning outcomes in the subject area concerned (solfège) these describe what can be predictably expected of students in terms of what they need to know, understand and be able to do upon successful completion of a given learning module, i.e. the development of vocal, psychomotor, rhythmic, hearing, melodic, harmonic, formal, expressive, tonal, creative and dynamic skills, as well as an indepth understanding of the different music codes and general and specific psychoeducational knowledge to correctly perform the task of teaching music in the primary classroom.

It must be borne in mind that learning outcomes are verifiable statements of what a learner is expected to know and be able to demonstrate after obtaining a given qualification, or after completion of a programme or its components. Thus a link is established between 
teaching, learning and assessment, allowing the calculation of workload and, with it, the award of credit.

The objectives laid down to provide an answer to the hypothesis are: (a) to identify the amount of time and levels of effort students expend on learning activities and their previous music background in musical education; (b) to identify the competencies, curriculum content and activities of teaching and learning where students experience most problems.

To meet these objectives, there is a need to further study: (a) the inverse relation between previous studies and the time and effort employed; (b) the inverse relation between the previous knowledge and the number of times the examination was taken, i.e. convocatorias; $^{1}$ (c) the confirmation of the adequacy of time allocated in the Music Subject guide to solfège (Esteve Faubel et al., 2006) for students with minimal musical background; and $(\mathrm{d})$ the difficulties experienced by students with limited prior music training when addressing practical questions in music performance.

To this end, the current experimental study was carried out with the aim of either confirming or refuting the hypothesis set out above. A descriptive correlational approach was followed. The study population was made up of primary schoolteacher trainees with a specialism in music from two Spanish public universities.

The findings allowed for ample discussion which translated into a number of recommendations valid for primary school trainees with a music specialism.

\section{Method}

\section{Participants}

The study population was made up of 270 students on a Primary Teaching with Music Specialism degree, during their first, second and third years at the University of Alicante (203 students) and a smaller group of third-year students in the Autonomous University of Madrid (67 students), both public universities. The data were gathered during the academic year 2006-2007 by means of a self-administered questionnaire. The latter institution was chosen because both universities had applied a similar curricular guide during the previous three years with regard to the content and skills to be acquired by beginning primary music teachers. Furthermore, teachers and researchers share a long history of collaboration. As a matter of fact, both universities worked in close cooperation in the design of the Music Subject Guide to Solfège (Esteve-Faubel et al., 2006) and the teaching guide for the Instrumental Training module (Esteve-Faubel et al., 2008) in line with the principles of the Bologna declaration. These subjects form part of the formal curriculum of the Primary Teaching with Music Specialism degree.

As the sample included all students with this subject area, no inclusion and exclusion criteria were defined. Moreover, all students share similar educational backgrounds: they have all passed the university entrance exam, they come from primary and secondary schools with identical curricula and they are of similar age.

The discrepancy in the number of participating students from the two universities is due to the fact that at the time the study was launched the University of Alicante had been putting the educational proposal into practice for four academic years and the Autonomous University of Madrid for only two years. 
This study, following Tejedor Tejedor (2003), has not considered the social and family background variable indicators, since these have little or no influence on university students. This is because the university is the last link in a series of filters, which means that the student population is quite homogeneous in its socioeconomic and cultural characteristics.

\section{Tests and tools}

The tool employed was a quantitative questionnaire for the assessment of time and effort of student learning, as proposed by Castejón Costa (2005).

This has been adapted to the subject characteristics and the objectives of the present research according to the results of qualitative investigation (Esteve Faubel et al., 2009).

There are three parts to the questionnaire:

1. The descriptive data of the student - gender, age, previous studies, number of times the examination has been taken (and subject), and number of European Credit Transfer System credits.

2. The strategies of the teaching and learning process concerned with the 'theory' credits.

3. The strategies of the teaching and learning process concerned with the 'practical' credits.

In the second and third parts, the task consisted of selecting the completed activities, and indicating the difficulty experienced by students on a scale from 1 to 5 (where $1=$ little difficulty and $5=$ maximum difficulty), together with the time taken to complete each activity. If an activity was undertaken that was not on the standard list, it was indicated in the 'others' section.

Prior to the study, a pilot project $(n=25)$ was launched to evaluate the clarity of the questions, to identify potential mistakes and to estimate the duration of the survey. Only some minor drafting corrections were made and some changes regarding the order of the questions.

\section{Procedure}

Before specifying the process of data collection of this study, it is important to indicate that the current solfège guide has been used for three academic years. It consists of:

- A professional profile of the music specialist primary teacher;

- A descriptor of the subject or object of study, according to the established government guidelines; and

- An introduction to the teaching context.

The introduction to the teaching context includes pre-requirements and a methodological proposal, where general learning objectives are stated along with the outcomes that the student should achieve by the end of the teaching period. Additionally, the required skills are structured according to more specific competencies organised around modules, facilitating a more practical way of working. Each module contains instrumental, interpersonal and systemic skills, as well as the content required to develop them. The 
teaching and learning methods, student work plan, assessment procedures and bibliography are included later in the guide.

For the research to be viable according to the chosen co-relational and descriptive methodology, the researchers included students from second and third years of the degree, as the number of first-year students was insufficient. The second- and third-year students had received the same methodological approach as the first-year students. The sample included an external control group of third-year students on the Primary Teaching with Music Specialism degree at the Autonomous University of Madrid - the purpose being to guarantee the validity and transferability of the research process. The data were obtained from the questionnaires, from which information was extracted concerning the time and effort employed by students in each of the activities, as well as applied strategies of teaching-learning. The groups of second- and third-year students from the University of Alicante completed the task on 23 February and 1 March 2007. First-year students took the test on 8 June 2007, before the final assessment in music. The purpose was to compare the first-year group with students from second and third years, to ascertain if their end-ofyear marks changed their perception about the subject and the teachers, amongst other variables. The 67 third-year students from the Autonomous University of Madrid completed the questionnaire during a session on 27 April of the same year.

\section{Data analysis}

The general method of the investigation and its objectives determine the choice of one or another type of analysis. A co-relational and descriptive methodology was employed in the data analysis. Firstly, a descriptive analysis of all the variables was undertaken. Secondly, the researchers undertook a correlation bi-varied analysis $-r$ Pearson - to estimate the relation between time and effort variables. Thirdly, a factor Analysis of Variance between groups (ANOVA) test was employed to compare the 'mean' of time expended that is, the hours dedicated to the study of the subject - total difficulty, examinations, difficulty in the practical part, and difficulty in the theoretical part, related to students from Conservatoire, ${ }^{2}$ schools/bands, and those without previous knowledge. Finally, a post hoc test was employed, consisting of multiple comparisons - Scheffé with the previous variables, with the computer program SPSS.16.

\section{Results}

Once the questionnaires and the resulting data were analysed, the following results were obtained. Table 3 describes the students who participated in the research.

The questionnaire was answered by 270 students (rate of answer: 90\%). The reason for abstention was non-attendance on the day the questionnaire was administered. The results indicate group heterogeneity with regard to the students' previous musical studies, especially the Conservatoire students (39.6\%), followed by those who did not have previous musical knowledge (31.1\%) and those from music schools/bands (29.3\%).

With regard to the relationship between, on the one hand, time and effort (or subject difficulty factors) and, on the other hand, previous knowledge, one can observe in Table 4 that correlations exist with a high degree of meaning $(r=750 ; p=0.01$ and $r=-729$; 
Table 3 Description of the participant students $(n=270)$

\begin{tabular}{|c|c|c|c|c|}
\hline \multicolumn{2}{|l|}{ University } & \multirow{2}{*}{$\frac{\text { Alicante }(n=203)}{69}$} & \multirow{2}{*}{$\begin{array}{l}\text { Madrid }(n=67) \\
22\end{array}$} & \multirow{2}{*}{$\frac{\text { Total }}{91}$} \\
\hline Gender & Male & & & \\
\hline & Female & 134 & 49 & 176 \\
\hline \multirow[t]{4}{*}{ Age (years) } & $18-20$ & 122 & 40 & 162 \\
\hline & $21-23$ & 40 & 17 & 57 \\
\hline & $24-25$ & 17 & 3 & 20 \\
\hline & $<25$ & 24 & 7 & 31 \\
\hline \multirow[t]{3}{*}{ Course } & $1^{\circ}$ & 65 & 0 & 65 \\
\hline & $2^{\circ}$ & 70 & 0 & 70 \\
\hline & $3^{\circ}$ & 68 & 67 & 135 \\
\hline \multirow[t]{3}{*}{ Previous studies } & Conservatoire & 96 & 11 & 107 \\
\hline & music schools/bands & 58 & 21 & 79 \\
\hline & without previous knowledge & 49 & 35 & 84 \\
\hline
\end{tabular}

Table 4 Correlations between the time and effort in the subject of solfège and previous knowledge, and total time taken

\begin{tabular}{llll}
\hline \hline & & Total difficulty & Total time taken \\
\hline Total Difficulty & Pearson correlation & 1 & $0.750\left(^{*}\right)$ \\
& Sign. (bilateral) & & 0.000 \\
& $\mathrm{~N}$ & 270 & 270 \\
Total time taken & Pearson correlation & $0.750\left(^{*}\right)$ & 1 \\
& Sign. (bilateral) & 0.000 & \\
& $\mathrm{~N}$ & 270 & 270 \\
\hline \multirow{5}{*}{ Total time taken } & & Total time used & Previous knowledge \\
& Pearson correlation & 1 & $-0.729\left(^{*}\right)$ \\
& Sign. (bilateral) & & 0.000 \\
Previous knowledge & $\mathrm{N}$ & 270 & 270 \\
& Pearson correlation & $-0.729\left(^{*}\right)$ & 1 \\
& Sign. (bilateral) & 0.000 & 270 \\
& $\mathrm{~N}$ & 270 & \\
\hline \hline
\end{tabular}

*The correlations are meaningful at level 0.01 (bilateral).

$p=0.01)$. This shows an increase in time when students perceive greater difficulty in the task and/or their previous musical background is limited.

At the same time, these data indicate a correspondence between the overall difficulty and previous knowledge $(r=-729$ and $p=0.01)$. The time taken to complete tasks is, as one might expect, related to the level of music education students have experienced

\section{CAMBRIDGE JDURNALS}


(Table 5). The students of the Conservatoire group on average take less time (123.1 hours), followed by the music schools/bands students (195 hours), while those who have not studied solfège previously take the longest (336.7 hours). The results of the factor ANOVA test and the post hoc test of multiple comparisons (Scheffé: $F=159.88 ; p=0.000$ ), demonstrate that the differences between the averages are significant. Thus, those who had experienced less music education take, on average, 213 hours more than those with better musical knowledge (Table 5).

The Musical Studies guide (Esteve Faubel et al., 2006) proposes that students should receive between 150 and 180 hours of music to complete tasks (equivalent to 6 in the European Credit Transfer System). The results of the present research reveal that students require varying amounts of support, depending on their musical background. In the same way, when the level of difficulty perceived by students is analysed according to their musical background (see Table 6), there are significant differences in the average figures $(F=1394.799 ; p=0.000$ ) between the most and least prepared groups (Conservatoire versus those without previous musical knowledge), underlining the importance of having an appropriate academic basis in the subject. Thus, on a scale from 1 to 5 across 38 items, the Conservatoire students register an average difficulty of 61.9 ; the music schools/bands students register 96.5; while those without previous musical knowledge register 142.1 .

Table 7 shows that the Conservatoire students take the examination once, on average; those from music schools 1.67 times; and those without previous musical knowledge 1.29 times. (This lower figure is due to some students not taking the examination.) When making multiple comparisons, the difference between averages is significant $(F=8.063 ; p=0.000)$, always in favour of the students from the first group. It should be noted that the number of times the examination was taken would have been slightly higher if the first-year students had undertaken the evaluation process, as suggested by the data.

Analysis of the number of times the examination was taken, together with the age of the participants, reveals a direct positive relationship $(r=207 ; p=0.01)$. Table 8 provides further information on this aspect.

Teaching and learning activities in music present different levels of difficulty, according to the perception of the students (Table 9). From their point of view, those aspects that create the fewest difficulties are: guidance for study (1.01), followed by the study of rhythm inside and outside the classroom (2.19); while those of greater difficulty include: singing melodic scales (3.54), along with the study of songs with changes of key (3.54).

The difficulty of the teaching and learning activities in the questionnaire was grouped into two types of activities - practical and theoretical. Taking into account students' previous musical background - Table 10, practical $(F=1155.745 ; p=0.000)$; Table 11, theoretical $(F=1329.333 ; p=0.000)$ - it is evident that the Conservatoire students experience the least difficulty: practical (34.9) and theory (27.03); followed by those from music schools/bands: practical (58.9) and theory (37.65); and finally, by those who do not have prior musical knowledge: practical (85.96) and theory (56.19). These data indicate that students without a suitable musical background have 2.5 times more difficulty in practical activities and 2.1 times greater difficulty in theoretical activities than the better-prepared students - the Conservatoire group.

\section{CAMBRIDGE JUURNALS}


Table 5 Differences in the mean hours of time used according to music studies background

\begin{tabular}{|c|c|c|c|c|c|}
\hline \multicolumn{6}{|c|}{ Descriptive statistics and mean comparison } \\
\hline & $\mathrm{N}$ & Mean (hours) & Typical deviation & \multicolumn{2}{|c|}{ Level of significance } \\
\hline Conservatoire & 107 & 123.1 & 29.9 & \multirow{4}{*}{0.0} & \\
\hline Schools/bands & 79 & 195 & 69.8 & & \\
\hline $\begin{array}{l}\text { Without previous } \\
\text { knowledge }\end{array}$ & 84 & 336.7 & 126.3 & & \\
\hline Total & 270 & 210.5 & 121.5 & & \\
\hline \multicolumn{6}{|c|}{ Multiple comparison } \\
\hline & (I) Previous studies & (J) Previous studies & $\begin{array}{c}\text { Mean difference } \\
\text { of hours }(\mathrm{I}-\mathrm{J})\end{array}$ & Typical Error & Sign. \\
\hline \multirow[t]{6}{*}{ Scheffé } & \multirow[t]{2}{*}{ Conservatoire } & Schools/bands & -71.9 & 12.2 & 0.000 \\
\hline & & $\begin{array}{l}\text { Without previous } \\
\text { knowledge }\end{array}$ & -213.6 & 12.0 & 0.000 \\
\hline & \multirow[t]{2}{*}{ Schools/bands } & Conservatoire & 71.9 & 12.2 & 0.000 \\
\hline & & $\begin{array}{l}\text { Without previous } \\
\text { knowledge }\end{array}$ & -141.7 & 12.9 & 0.000 \\
\hline & \multirow{2}{*}{$\begin{array}{l}\text { Without previous } \\
\text { knowledge }\end{array}$} & Conservatoire & 213.6 & 12.0 & 0.000 \\
\hline & & Schools/bands & 141.7 & 12.9 & 0.000 \\
\hline
\end{tabular}

\section{CAMbridge}


Table 6 Differences in the mean hours of total difficulty according to music studies background

\begin{tabular}{|c|c|c|c|c|c|}
\hline \multicolumn{6}{|c|}{ Descriptive statistics and mean comparison } \\
\hline & $\mathrm{N}$ & Mean & Typical deviation & \multicolumn{2}{|c|}{ Level of significance } \\
\hline Conservatoire & 107 & 61.9 & 13.5 & \multirow{4}{*}{0.0} & \\
\hline Schools/bands & 79 & 96.5 & 4.6 & & \\
\hline $\begin{array}{l}\text { Without previous } \\
\text { knowledge }\end{array}$ & 84 & 142.1 & 9.4 & & \\
\hline Total & 270 & 96.8 & 35.1 & & \\
\hline \multicolumn{6}{|c|}{ Multiple comparison } \\
\hline & (I) Previous studies & (J) Previous studies & Mean difference (I-J) & Typical error & Sign. \\
\hline \multirow[t]{6}{*}{ Scheffé } & \multirow[t]{2}{*}{ Conservatoire } & Schools/bands & -34.5 & 1.5 & 0.000 \\
\hline & & $\begin{array}{l}\text { Without previous } \\
\text { knowledge }\end{array}$ & -80.1 & 1.5 & 0.000 \\
\hline & \multirow[t]{2}{*}{ Schools/bands } & Conservatoire & 34.5 & 1.5 & 0.000 \\
\hline & & $\begin{array}{l}\text { Without previous } \\
\text { knowledge }\end{array}$ & -45.6 & 1.6 & 0.000 \\
\hline & \multirow{2}{*}{$\begin{array}{l}\text { Without previous } \\
\text { knowledge }\end{array}$} & Conservatoire & 80.1 & 1.5 & 0.000 \\
\hline & & Schools/bands & 45.6 & 1.6 & 0.000 \\
\hline
\end{tabular}

\section{CAMBRIDGE}


Table 7 Differences in the mean hours of examination according to music studies background

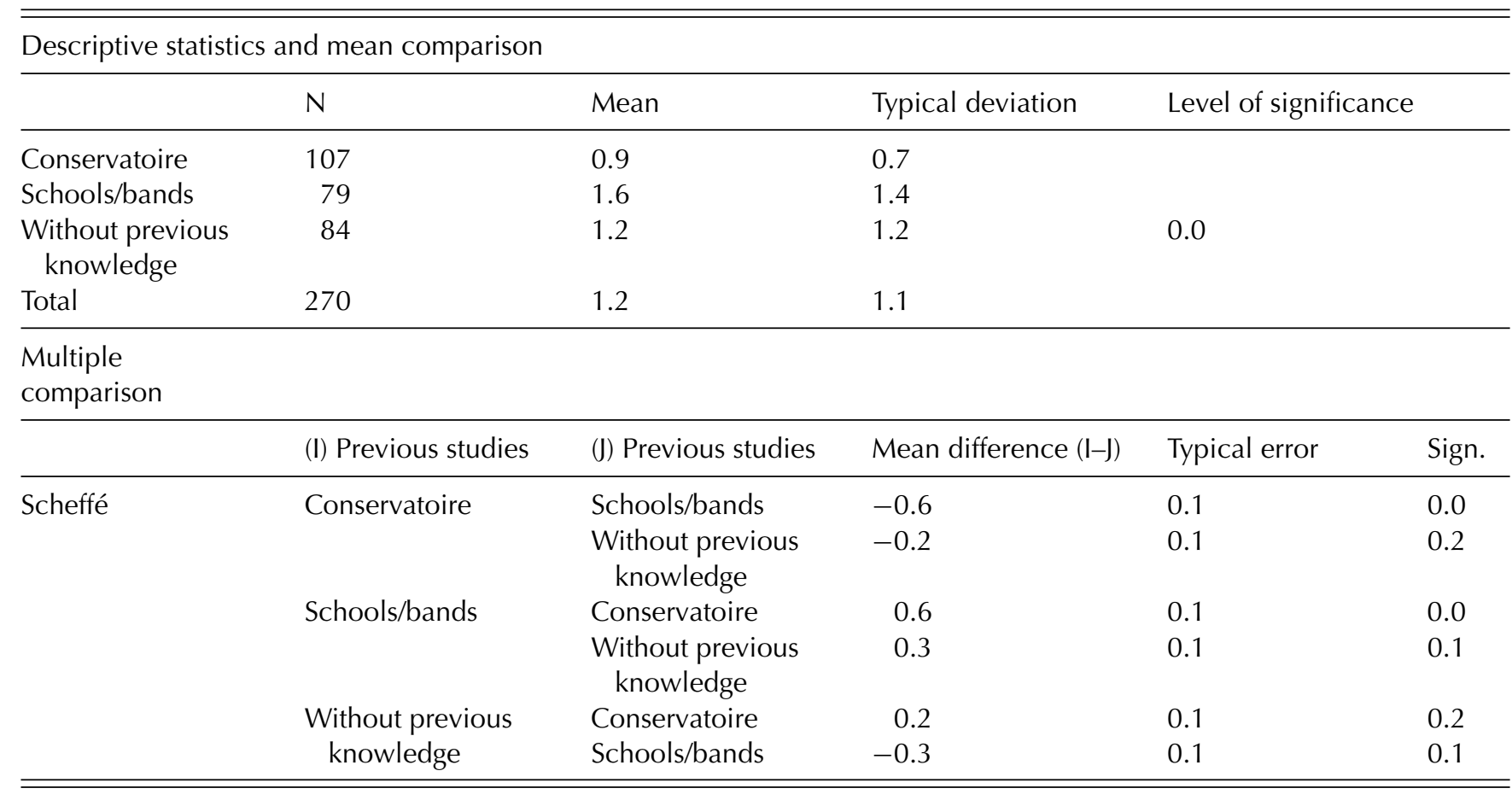

\section{CAMbridge}


Table 8 Differences in the number of times the examination was taken (Convocatorias) according to student age

\begin{tabular}{lrlll}
\hline \hline \multicolumn{2}{l}{ Descriptive statistics } \\
\multicolumn{2}{l}{ Age groups N } & Mean & Typical deviation & Level of significance \\
\hline $18-20$ & 162 & 1.12 & 1.06 & \\
$21-23$ & 55 & 1.41 & 1.32 & 0.000 \\
$24-25$ & 21 & 1.60 & 1.04 & \\
25 & 32 & 1.81 & 1.32 & \\
Total & 270 & 1.29 & 1.17 & \\
\hline
\end{tabular}

Multiple comparison

(I) Convocatorias (J) Convocatorias Mean difference (I-J) Typical error Sign.

\begin{tabular}{|c|c|c|c|c|}
\hline \multirow[t]{7}{*}{ Scheffé } & 1 & 0.3 & 0.1 & 0.5 \\
\hline & 2 & -0.3 & 0.1 & 0.5 \\
\hline & 3 & -0.4 & 0.1 & 0.2 \\
\hline & 4 & -1.1 & 0.5 & 0.4 \\
\hline & 5 & 0.1 & 0.7 & 1.0 \\
\hline & 0 & -0.3 & 0.1 & 0.5 \\
\hline & 2 & -0.6 & 0.1 & 0.0 \\
\hline \multirow[t]{5}{*}{1} & 3 & -0.7 & 0.1 & 0.0 \\
\hline & 4 & -10.4 & 0.5 & 0.1 \\
\hline & 5 & -0.1 & 0.7 & 1.0 \\
\hline & 0 & 0.3 & 0.1 & 0.5 \\
\hline & 1 & 0.6 & 0.1 & 0.0 \\
\hline \multirow[t]{5}{*}{2} & 3 & -0.1 & 0.1 & 0.9 \\
\hline & 4 & -0.8 & 0.5 & 0.7 \\
\hline & 5 & 0.4 & 0.7 & 0.9 \\
\hline & 0 & 0.4 & 0.1 & 0.2 \\
\hline & 1 & 0.7 & 0.1 & 0.0 \\
\hline \multirow[t]{5}{*}{3} & 2 & 0.1 & 0.1 & 0.9 \\
\hline & 4 & -0.6 & 0.5 & 0.9 \\
\hline & 5 & 0.5 & 0.7 & 0.9 \\
\hline & 0 & 1.1 & 0.5 & 0.4 \\
\hline & 1 & 1.4 & 0.5 & 0.1 \\
\hline \multirow[t]{5}{*}{4} & 2 & 0.8 & 0.5 & 0.7 \\
\hline & 3 & 0.6 & 0.5 & 0.9 \\
\hline & 5 & 1.2 & 0.8 & 0.8 \\
\hline & 0 & -0.1 & 0.7 & 1.0 \\
\hline & 1 & 0.1 & 0.7 & 1.0 \\
\hline \multirow[t]{3}{*}{5} & 2 & -0.4 & 0.7 & 0.9 \\
\hline & 3 & -0.5 & 0.7 & 0.9 \\
\hline & 4 & -1.2 & 0.8 & 0.8 \\
\hline
\end{tabular}

\section{CAMBRIDGE}


Table 9 Statistical descriptive of the levels of difficulty (scale from 1 to 5) in each one of the teaching/learning strategies

\begin{tabular}{|c|c|c|c|c|}
\hline & Minimum & Maximum & Average & $\begin{array}{l}\text { Standard } \\
\text { deviation }\end{array}$ \\
\hline Difficulty in lesson/teacher explanation & 1 & 5 & 2.9 & 1.3 \\
\hline Difficulty in studying notation & 1 & 5 & 3 & 1.2 \\
\hline $\begin{array}{l}\text { Difficulty in studying/researching outside the } \\
\text { classroom }\end{array}$ & 2 & 5 & 3.2 & 1 \\
\hline Difficulty in explaining work (monograph) & 2 & 5 & 3.1 & 1 \\
\hline $\begin{array}{l}\text { Difficulty in reading and commenting on } \\
\text { works made by students }\end{array}$ & 2 & 4 & 2.9 & .8 \\
\hline Difficulty in reading texts in classroom & 1 & 5 & 2.9 & 1.2 \\
\hline $\begin{array}{l}\text { Difficulty in reading works, articles etc. } \\
\text { outside classroom }\end{array}$ & 2 & 5 & 3.1 & 1.1 \\
\hline $\begin{array}{l}\text { Difficulty in learning/completing exercises } \\
\text { on-line }\end{array}$ & 1 & 4 & 2.3 & 1 \\
\hline Difficulty in study guidance & 1 & 2 & 1 & .1 \\
\hline $\begin{array}{l}\text { Difficulty in checking individual } \\
\text { uncertainties/lack of understanding }\end{array}$ & 1 & 4 & 2.3 & 1.1 \\
\hline Difficulty in preparation of the theory test & 1 & 5 & 3 & 1.2 \\
\hline Difficulty in preparation of the practical test & 0 & 5 & 2.2 & 1.7 \\
\hline $\begin{array}{l}\text { Difficulty in teacher's explanation of } \\
\text { methodological questions }\end{array}$ & 1 & 5 & 2.2 & 1.2 \\
\hline $\begin{array}{l}\text { Difficulty in the melodic scales in rhythm } \\
\text { lessons in the classroom }\end{array}$ & 1 & 5 & 2.2 & 1.3 \\
\hline $\begin{array}{l}\text { Difficulty in the study of rhythm lessons } \\
\text { outside the classroom }\end{array}$ & 1 & 5 & 2.2 & 1.3 \\
\hline $\begin{array}{l}\text { Difficulty in singing the scales in melodic } \\
\text { songs in the classroom }\end{array}$ & 1 & 5 & 3.5 & 1.4 \\
\hline $\begin{array}{l}\text { Difficulty in singing the scales in melodic } \\
\text { songs outside the classroom }\end{array}$ & 1 & 5 & 3.5 & 1.4 \\
\hline $\begin{array}{l}\text { Difficulty in the scales of songs with key } \\
\text { changes in the classroom }\end{array}$ & 1 & 5 & 3.5 & 1.4 \\
\hline $\begin{array}{l}\text { Difficulty in the scales of songs with key } \\
\text { changes outside the classroom }\end{array}$ & 1 & 5 & 3.5 & 1.4 \\
\hline $\begin{array}{l}\text { Difficulty in the scales in folk songs in the } \\
\text { classroom }\end{array}$ & 1 & 5 & 3.2 & 1.4 \\
\hline $\begin{array}{l}\text { Difficulty in the scales in folk songs outside } \\
\text { the classroom }\end{array}$ & 1 & 5 & 3.1 & 1.5 \\
\hline $\begin{array}{l}\text { Difficulty in musical dictation in the } \\
\text { classroom }\end{array}$ & 1 & 5 & 3.3 & 1.4 \\
\hline $\begin{array}{l}\text { Difficulty in musical dictation outside the } \\
\text { classroom }\end{array}$ & 1 & 5 & 3.2 & 1.5 \\
\hline
\end{tabular}




\begin{tabular}{lllll}
\hline \hline & & & & $\begin{array}{c}\text { Standard } \\
\text { deviation }\end{array}$ \\
& Minimum & Maximum & Average & devion \\
\hline $\begin{array}{l}\text { Difficulty in individual improvisations and } \\
\quad \text { compositions }\end{array}$ & 2 & 5 & 3.2 & 1.1 \\
$\begin{array}{l}\text { Difficulty in group practical work } \\
\begin{array}{l}\text { Difficulty in practical learning and } \\
\quad \text { completing exercises on-line }\end{array}\end{array}$ & 2 & 5 & 3.2 & 1.1 \\
$\begin{array}{l}\text { Difficulty in checking individual } \\
\text { uncertainties/lack of understanding }\end{array}$ & 1 & 5 & 3.1 & 1.2 \\
$\begin{array}{l}\text { Difficulty in checking practical uncertainties } \\
\quad \text { in the group }\end{array}$ & 1 & 4 & 2.3 & 1.1 \\
$\begin{array}{l}\text { Difficulty in preparation for practical test } \\
\text { Difficulty in the practical test }\end{array}$ & 1 & 4 & 2.4 & 1.1 \\
\hline \hline
\end{tabular}

\section{Discussion and conclusions}

The results of this research show a direct and positive relationship between the time taken and the difficulty experienced by students on the Primary Teaching programmes at the University of Alicante and the Autonomous University of Madrid (the control group). Invariably, the better the music education before students enter university, the greater their success rate; conversely, where students lack an adequate music education, they experience greater difficulties and spend more time on tasks than those who already have had a systematic approach to music learning. As a consequence, Conservatoire students, on the whole, take the examination fewer times than those from Music schools/bands or those without previous musical knowledge.

These results confirm that, in the field of music education, the academic variables (described at the start of this article) pertaining to university student performance (Tourón Figueroa, 1984, 1985; Gaviria Soto et al., 1986; Apodaka et al., 1991; Tejedor Tejedor, 2003) are a crucial factor in student learning and achievement. Interestingly, while the students from music schools/bands have, in general, a deficient musical understanding, their perception is the opposite. This is why this particular group needs to retake the examination more than others. In contrast, the students with no previous knowledge tend not to take the examination, as they understand that it would be very difficult for them to achieve the required skills in such a short time (Lizzio et al., 2002). Age is another factor related to the number of times the examination is taken. The younger the students, and the closer they are to their previous musical studies before entering university, the greater their chance of passing the examination first time. Additionally, the analysis of the surveys supports the general perception that students must engage in independent work as part of their music education. At the outset, students are aware of the great volume of work required to support their music education and of the difficulties in mastering the required knowledge and skills in a relatively short time. This factor is compounded by a lack of experience of private study in music prior to university. In the case of the Conservatoire group, it is evident

\section{CAMBRIDGE JDURNALS}


Table 10 Differences in the mean hours of the practical part to music studies background

\begin{tabular}{|c|c|c|c|c|c|}
\hline \multicolumn{6}{|c|}{ Descriptive statistics } \\
\hline & $\mathrm{N}$ & Mean & Typical deviation & \multicolumn{2}{|c|}{ Level of significance } \\
\hline Conservatoire & 107 & 34.9 & 10.4 & \multirow{3}{*}{0.0} & \\
\hline Schools/bands & 79 & 58.9 & 2.8 & & \\
\hline $\begin{array}{l}\text { Without previous } \\
\text { knowledge }\end{array}$ & 84 & 85.8 & 4.6 & & \\
\hline Total & 270 & 57.7 & 22.5 & & \\
\hline \multicolumn{6}{|c|}{ Multiple comparison } \\
\hline & (I) Previous studies & (J) Previous studies & Mean difference (I-J) & Typical Error & Sig. \\
\hline \multirow[t]{6}{*}{ Scheffé } & \multirow[t]{2}{*}{ Conservatoire } & Schools/bands & -23.9 & 1.0 & 0.000 \\
\hline & & $\begin{array}{l}\text { Without previous } \\
\text { knowledge }\end{array}$ & -50.9 & 1.0 & 0.000 \\
\hline & \multirow[t]{2}{*}{ Schools/bands } & Conservatoire & 23.9 & 1.0 & 0.000 \\
\hline & & $\begin{array}{l}\text { Without previous } \\
\text { knowledge }\end{array}$ & -26.9 & 1.1 & 0.000 \\
\hline & \multirow{2}{*}{$\begin{array}{l}\text { Without previous } \\
\text { knowledge }\end{array}$} & Conservatoire & 50.9 & 1.0 & 0.000 \\
\hline & & Schools/bands & 26.9 & 1.1 & 0.000 \\
\hline
\end{tabular}

\section{CAMbridge}


Table 11 Differences in the mean hours of the theoretical part to music studies background

\begin{tabular}{|c|c|c|c|c|c|}
\hline \multicolumn{6}{|c|}{ Descriptive statistics and mean comparison } \\
\hline & $\mathrm{N}$ & Mean & Typical deviation & \multicolumn{2}{|c|}{ Level of significance } \\
\hline Conservatoire & 107 & 27.0 & 3.6 & \multirow{4}{*}{0.0} & \\
\hline Schools/bands & 79 & 37.6 & 2.2 & & \\
\hline $\begin{array}{l}\text { Without previous } \\
\text { knowledge }\end{array}$ & 84 & 56.1 & 5.1 & & \\
\hline Total & 270 & 39.1 & 12.8 & & \\
\hline \multicolumn{6}{|c|}{ Multiple comparison } \\
\hline & (I) Previous studies & (J) Previous studies & Mean difference $(\mathrm{I}-\mathrm{J})$ & Typical Error & Sig. \\
\hline \multirow[t]{6}{*}{ Scheffé } & \multirow{2}{*}{ Conservatoire } & Schools/bands & -10.6 & 0.5 & 0.000 \\
\hline & & $\begin{array}{l}\text { Without previous } \\
\text { knowledge }\end{array}$ & -29.1 & 0.5 & 0.000 \\
\hline & \multirow[t]{2}{*}{ Schools/bands } & Conservatoire & 10.6 & 0.5 & 0.000 \\
\hline & & $\begin{array}{l}\text { Without previous } \\
\text { knowledge }\end{array}$ & -18.5 & 0.6 & 0.000 \\
\hline & \multirow[t]{2}{*}{$\begin{array}{l}\text { Without previous } \\
\text { knowledge }\end{array}$} & Conservatoire & 29.1 & 0.5 & 0.000 \\
\hline & & Schools/bands & 18.5 & 0.6 & 0.000 \\
\hline
\end{tabular}

\section{CAMbridge}


that as their experience progresses, their perception of self-study improves - whereas the perception of students from the music schools/bands and those without musical studies (particularly the latter group) evidently worsens because of their serious difficulties in understanding set musical texts, leading to a demand for increased preparation time. All the groups lack experience of self-study and, as a consequence, do not properly value it (Boekaerts, 1997, 1999).

In the survey, university tutoring is highly criticised by students, not because of poor musical content or lack of preparation by lecturers, but because of the impossibility of allocating students sufficient time to support their learning. In this context, it is worth noting that each tutor has between 90 and 100 students in solfège classes.

A coherent explanation for the argument at this stage lies in the analysis of solfège in music teacher education and the Spanish course specification, which is the purpose of this study. Solfège is the subject on which all other musical activities are based (Alonso Marín, 2004; Esteve Faubel et al., 2006), with a series of very special characteristics that require time and dedication to develop and integrate a succession of skills rhythmical, auditory, pitching, together with an appropriate theoretical background. The questionnaires reflect these concerns. Students indicate that their greatest difficulty in the acquisition of musical knowledge, understanding and skills occurs mainly in the development of practical abilities, such as singing melodic scales, especially those that modulate to another key. The origin of the problem lies in the lack of assimilation and integration of theoretical understanding that is shown in a practical context, since (as has already been stated) this mastery occurs only by means of systematic work over time.

Evidence from the present study would support the current allocation of time and effort in the course specification, but only for Conservatoire students. Clearly, the proposed allocation is inadequate for the rest of the student body; those who come from the music schools/bands reduce the number of times they fail from the second year of their musical studies programme, which is why it is necessary to consider what should be done to support this group of students. The European Higher Education Area aims to offer such things as quality of course provision and employability (Reichert \& Tauch, 2003), despite the fact that almost all the students - irrespective of the group they belong to - believe the course specification is suitable. Students in the sample were positive regarding their music education, although they considered that much more time would be required to develop necessary musical skills.

A literature review undertaken by the Spanish authors of this article revealed an absence of previous studies in music education that might support or counter the findings of the present study, particularly for the group that could be labelled 'semi-failure' that is, those students who come from the music schools/bands; and those that could be labelled 'failure' - that is, those students who do not have any type of previous musical background (knowledge and skills). It is these two groups of students who present the greatest methodological concern in the research project. The success of the course specification (time-effort), a priori, is directly related to the quality of students' previous music education, since it allows them to be more effective in controlling the situations they face. It would be desirable, therefore, for all students who enter a course of teacher education in music to have had a solid musical background. 
It is necessary to state that data gathered for this study are not absolutely conclusive, nor is there a guarantee of success in all instances described in the research; further consideration needs to be given to the influence of other variables, yet to be investigated. Nevertheless, what is clear in the current study is that two related variable factors (knowledge and age) appear to have a notable influence on results. In order to evaluate effectively the strengths and variables of the present study in a pertinent way, and to respond to the lack of related studies already mentioned, the research group has also made a qualitative investigation of the same topic (Esteve Faubel et al., 2009). The students in that study answered in a freer form the questions raised, producing very similar results. It is thus reasonable to infer that the conclusions of this quantitative study are valid, notwithstanding that these may be open to future interpretations. When making comparisons with other relevant research work, or referring to university educational matters in general, the present research indicates that student performance improves the less time there is between their school music education and entrance to a university course (Sánchez Gómez, 1996; Tejedor Tejedor, 1998, 2003; Heikkilaumla \& Lonka, 2006). Thus, according to the present study, those students who enter university with a good previous musical background and who have been successful in the university entrance examination have a greater probability of success.

It would be advisable to supplement the current research by undertaking a detailed study of teachers' musical background and teaching methodologies (Simon, 2002). In this regard, it is worthy of note that the Technical Unit of Quality (TUC) of the University of Alicante, which annually audits this variable and publishes its results, agrees with the present research - namely, a high degree of satisfaction with the education and pedagogical approaches, and a low degree of satisfaction with the time allotted to the subject. Nevertheless, we have to conclude that it is not possible to be completely confident in this area, as this situation should be compared with other studies of this type, which presently do not exist. This fact limits a proper evaluation of the research methodology employed in this study, as it does not allow comparisons to be made with other studies in the same field. However, the results from similar studies in related educational fields support the conclusions of the present study, which would suggest that the present study should be considered valuable in this regard.

\section{Recommendations}

The first aspect to be addressed to ensure students gain most from their education is the inadequate allocation of time to such a fundamental subject as music education. This is particularly so for the groups from the music schools/bands and those without previous musical studies, although it is interesting that students from the Conservatoire indicate also their need for an increase in study time. Most Spanish universities have arrived at the same conclusion (Facultat d'Educació Illes Balears, 2005). Consequently, they have introduced both compulsory and optional subjects, increased the teaching load for musical studies, and established a better balance between the general education of primary teachers and their subject specialism (Facultat d'Educació Illes Balears, 2005). However, the results are not as expected. The Autonomous University of Madrid (the control group for the present research) practices this policy, as they have a high proportion of students without

\section{CAMBRIDGE JDURNALS}


previous musical knowledge (52.2\%). Nevertheless, the increase in lecturers' teaching load (12 European Credit Transfer System) has proven insufficient for students to obtain the skills demanded by school and society. These results suggest the need to develop ways of intervention and selection in music education that do not require a dramatic increase in the teaching schedule and which are in agreement with the structuring of the new curricula (Remus \& Wong, 1982), where the generalist teacher is considered more important (in terms of teacher preparation) than the specialist teacher.

Following Rodríguez-Quiles y García (2004), if universities are to provide well qualified Music teachers for any educational level, students should receive serious epistemological, psychological and methodological training; in other words, students must combine professional training as a teacher with that required for a musician (Stephens, 1995; Esteve Faubel et al., 2006, 2009).

In general, the lack of solid previous knowledge in the subject area students wish to undertake at university suggests the need to develop ways of student selection and intervention. Students should receive serious epistemological, psychological and methodological training (Esteve-Faubel et al., 2006) in order to achieve the goals set in the European Higher Education Area in terms of quality and employability among other aspects.

Additionally, it would be necessary to reconsider the student-teacher ratio, as the current standard ratio of 1 teacher to 90 or 100 students in Spain makes it impossible to properly address methodological implications of the course specification. Notwithstanding advances in virtual education, by means of Information Technology tools such as Virtual Campus, $^{3}$ the volume of the teaching load that so many students generate makes the correct application of the European Credit Transfer System philosophy non-viable. Either the number of teachers has to be increased considerably or the number of students should decrease commensurately.

Although these findings relate to a Spanish investigation they are easily transferable to other EU countries. They suggest that:

(a) It is desirable that students prior to enrolling in university receive proper training in the subject area they wish to undertake at university, since the achieved learning outcomes depend on the students' own contexts and circumstances as well as on the physical environment and material constraints.

(b) Taking into account students' heterogeneous background knowledge and the fact that classes contain at least 60 students, the majority of whom lack a solid background in their subject area, university teachers may find it hard to make proper use of all the pedagogical tools in order to develop a teaching guide in accordance with the Bologna guidelines.

(c) As shown in Table 7, it is possible as is shown by the results of this study but at the expense of a dramatic increase in the teaching-learning time. In other words, students with little or no previous music training need several years of study -increase in time - in order to pass.

(d) Following point (c) and ignoring the time factor, Edwards rightly states that:

Placing learners at the heart of the learning process and meeting their needs, is taken to a progressive step in which learner-centred approaches mean that 
persons are able to learn what is relevant for them in ways that are appropriate. Waste in human and educational resources is reduced as it suggested learners no longer have to learn what they already know or can do, nor what they are uninterested in. (Edwards, 2001, p. 37)

(e) As Stephen (2004, p. 28) rightly states:

The traditional input-related curriculum has proved to be too focused on the teacher instead of the learner. Consequently there is what has been described as a paradigm shift underway, moving the emphasis from teaching to learning and to embrace student-centred learning. This change has been associated with a need for more precision in curriculum design, and an acknowledgement that more effective and varied learning styles can benefit the learner.

(f) The study raises the question as to whether teachers should be responsible for defining the learning outcomes of the programme components and for describing learning activities and calculating the workload required to complete them, or whether it is really up to higher education institutions to decide from the beginning how to standardise and predefine the extent of the academic components adjusting the workload to the number of credits allocated per programme component.

(g) Student workload should be reviewed from time to time following the information provided by students.

To conclude, we would suggest that all these aspects should be considered in order to address the challenge of teaching and the harmonisation of curricula proposed by the European Higher Education Area (O'Neill et al., 2005).

As illustrated in this study, it is possible to achieve the harmonisation of the European university system, in a way that ensures comparability of teaching guides in terms of design and efficiency according to the skills graduates need to acquire and so as to maximise the learning (Rozendaal et al., 2005; Jacobs \& Van Der Ploeg, 2006b), at least in theory.

In practice, however, and according to this study, the key problem is students' training prior to enrolling at university, which can affect higher education policy and practice.

The quality of this previous training has been studied in the PISA report. ${ }^{4}$ It reveals a considerable disparity in students' performance between education systems in the EU depending on the curricula of the Member States. Hence, apart from addressing the issue of the European Higher Education Area, far-reaching changes at all educational levels are necessary to live up to the tenets of the Bologna Declaration.

This study reveals that there is a need for a profound change in the new conception of education, which implies greater involvement of students in the design of their own learning and more precision in the curriculum design. Hence, teachers and students will necessarily need to learn about time management, among other things, and they will need to enhance their teaching and learning skills so as to ensure the quality of teaching, learning and assessment.

However, these results in the field of higher education are subject to students' prior music training when enrolling at university. For students who lack an adequate training it will be difficult to engage in the dynamics marked by the European Credit Transfer System. Hence, it is much harder for them to achieve academic success within the allotted time.

\section{CAMBRIDGE JDURNALS}


In general, the study carried out suggests that, without common criteria for the European Higher Education Area in terms of learning outcomes, all of the proposed changes will be ineffective.

\section{Notes}

1 Convocatorias: Spanish university students take examinations in June of each year of their degree. If they fail an examination, they are permitted to take it again in September and subsequently five more times.

2 Conservatoire is a prestigious network of Spanish state run music schools where music education is administered and certified. Their standards are highly respected within the musical community.

3 Virtual Campus is the on-line university platform at Alicante University to support student learning; other universities operate similar systems - albeit, with different nomenclature.

4 PISA (Programme for International Student Assessment) is a worldwide comparative study conducted by the Organisation for Economic Co-operation and Development (OECD). It aims to evaluate the educational achievement of 15 -year-old students in three key competencies: reading, mathematics and sciences. PISA surveys take place every three years. The first PISA survey was conducted in 2000.

\section{References}

ALONSO MARÍN, M. J. (2004) Perfil musical y rendimiento académico en alumnos de Música de Magisterio. Música y educación: Revista trimestral de pedagogía musical, 17, 57, 77-102.

APODAKA, P., GRAO, J., MARTÍNEZ, J. \& ROMO, I. (1991) Demanda y rendimiento académico en educación superior. Estudio longitudinal de la inserción de dos cohortes de bachillerato en la UPV/EHU. Vitoria-Gasteiz, Servicio Central de Publicaciones del Gobierno del País Vasco.

BETTS, J. R. \& MORELL, D. (1999) The determinants of undergraduate grade point average: the relative importance of family background, high school resources, and peer group effects. Journal of Human Resources, 34, 268-293.

BOEKAERTS, M. (1997) Self-regulated learning: a new concept embraced by researchers, policy makers, educators, teachers, and students. Learning and Instruction, 7, 161-186.

BOEKAERTS, M. (1999) Self-regulated learning: where we are today. International Journal of Educational Research, 31, 445-457.

BRANDES, D. \& GINNIS, P. (1996) A guide to Student-centred Learning. Oxford: Nelson Thornes.

CARLILE, O. \& JORDAN, A. (2005) It works in practice but will it work in theory? The theoretical underpinnings of pedagogy. In G. O'Neill, S. Moore \& B. McMullin (Eds), Emerging Issues in the Practice of University Learning and Teaching, pp. 11-26. Dublin: AISHE.

CASTEJÓN COSTA, J. L. (2005) Cuestionario Cuantitativo para medir el tiempo y el esfuerzo de aprendizaje del alumno. Alicante: Universidad de Alicante.

COHN, E., COHN, S., BALCH, D. C. \& BRADLEY, J. (2004) Determinants of undergraduate GPAs: SAT scores, high-school GPA and high-school rank. Economics of Education Review, 23, 577-586.

DECLARATION OF BERGEN (2005) The European Higher Education Area - Achieving the Goals. Communiqué of the meeting of European Ministers in charge of Higher Education, from http://www.ehea.info/Uploads/Declarations/Bergen_Communique1.pdf

DECLARATION OF BERLIN (2003) Realising the European Higher Education Area. Communiqué of the Conference of Ministers responsible for Higher Education Available from http://www.sc.ehu.es/siwebso/Bolonia/textos/AEES_EHEA/Berlin_declaration.pdf

DECLARATION OF BOLOGNA (1999) Joint declaration of the European Ministers of Education. Communiqué of the meeting of European Ministers in charge of Higher Education Available from http://www.ehea.info/Uploads/Declarations/BOLOGNA_DECLARATION1.pdf 
DECLARATION OF PRAGUE (2001) Towards the European Higher Education Area. Communiqué of the meeting of European Ministers in charge of Higher Education Available from http://www.ehea. info/Uploads/Declarations/PRAGUE_COMMUNIQUE.pdf

EDWARDS, R. (2001) Meeting individual learner needs: power, subject, subjection. In C. Paechter, M. Preedy, D. Scott \& J. Soler (Eds), Knowledge, Power and Learning, pp. 37-46. London: Sage.

ESTEVE-FAUBEL, J. M., ESPINOSA ZARAGOZA, J. A., MOLINA VALERO, M. Á. \& LÓPEZ DE REGO FERNÁNDEZ, C. (2006) Elaboración de una guía docente de maestro en educación musical adaptada al programa de convergencia europea en educación superior: lenguaje musical. Música y educación: Revista trimestral de pedagogía musical, 16, 127-148.

ESTEVE-FAUBEL, J. M., LÓPEZ DE REGO FERNÁNDEZ, C., MOLINA VALERO, M. A. \& ESPINOSA ZARAGOZA, J. A. (2008). Guía docente de formación instrumental. Música y educación: Revista trimestral de pedagogía musical, 21, 73, 140-155.

ESTEVE-FAUBEL, J. M., MOLINA VALERO, M. Á. \& STEPHENS, J. (2009) A qualitative assessment of students. Music Education Research, 11, 241-265.

FACULTAT D’EDUCACIÓ ILLES BALEARS (2005) Informe de autoevaluación. Palma de Mallorca: Universitat de les Illes Balears.

GAVIRIA SOTO, J. L., DE LA ORDEN HOZ, A. \& GARCÍA RAMOS, J. M. (1986) Un acercamiento experimental a la investigación del rendimiento en la Universidad. Revista de investigación educativa (RIE), 4 (8), 21-36.

GIBBS, G. (1995) Assessing Student-centred Courses. Oxford: Oxford Centre for Staff Learning and Development.

GONZÁLEZ, J. \& WAGENAAR, R. (2003) Tuning educational structures in Europe. Informe final. Fase, 1, Bilbao: Universidad de Deusto.

HALL, J. \& SAUNDERS, P. (1997) Adopting a student-centred approach to management of learning. In C. Bell, M. Bowden \& A. Trott (Eds), Implementing Flexible Learning. London: Kogan Page.

HARDEN, R. M. \& CROSBY, J. R. (2000) AMEE Guide No 20: The good teacher is more than a lecturer the twelve roles of the teacher. Medical Teacher, 22, 334-347.

HEIKKILAUMLA, A. \& LONKA, K. (2006) Studying in higher education: students' approaches to learning, self-regulation, and cognitive strategies. Studies in Higher Education, 31, 99-117.

HOUSE, J. D., HURST, R. S. \& KEELY, E. J. (1996) Relationship between learner attitudes, prior achievement, and performance in a general education course: a multi-institutional study. International Journal of Instructional Media, 23, 257-271.

JACOBS, B. \& VAN DER PLOEG, F. (2006a) Getting European universities into shape. European Political Science, 5, 288-303.

JACOBS, B. \& VAN DER PLOEG, F. (2006b) Guide to reform of higher education: a European perspective. Economic Policy, 21, 535-592.

KELLY, A. E. (2003) Research as design. Educational Researcher, 32, 3-4.

KIRSTI, L. \& KIRSI, A. (1995) Activating instruction: How to foster study and thinking skills in higher education. European Journal of Psychology of Education, 10, 351-368.

KOPER, R. \& OLIVIER, B. (2004) Representing the learning design of units of learning. Educational Technology and Society, 7, 97-111.

LEA, S. J., STEPHENSON, D. \& TROY, J. (2003) Higher education students' attitudes to student-centred learning: beyond 'educational bulimia'? Studies in Higher Education, 28, 321-334.

LIZZIO, A., WILSON, K. \& SIMONS, R. (2002) University students' perceptions of the learning environment and academic outcomes: implications for theory and practice. Studies in Higher Education, 27, $27-52$.

O'NEILL, G., MOORE, S. \& MCMULLIN, B. (2005) Emerging Issues in the Practice of University Learning and Teaching. Dublin: All Ireland Society for Higher Education (AISHE).

\section{CAMBRIDGE JDURNALS}


REICHERT, S. \& TAUCH, C. (2003) Trends 2003: Progress Towards the European Higher Education Area. Geneve-Brussels: European Association.

REICHERT, S. \& TAUCH, C. (2005) Trends IV: European Universities Implementing Bologna. Brussels: European University Association.

REMUS, W. \& WONG, C. (1982) An evaluation of five models for the admissions decision. College Student Journal, 16, 53-59.

RODRÍGUEZ-QUILES Y GARCÍA, J. A. (2004) Competencias del profesor y experiencias previas del alumno: Puntos de encuentro para el cambio en el Aula de Música. Revista electrónica de LEEME. Logroño, Universidad de La Rioja.

ROZENDAAL, J. S., MINNAERT, A., \& BOEKAERTS, M. (2005) The influence of teacher perceived administration of self-regulated learning on students' motivation and information-processing. Learning and Instruction, 15 (2), 141-160.

SÁNCHEZ GÓMEZ, M. C. (1996) Determinantes del rendimiento académico en la Universidad de Salamanca. Métodos de investigación y diagnóstico en educación. Salamanca: Universidad de Salamanca.

SIMON, B. (2002) Why no pedagogy in England? In J. Leach \& B. Moon (Eds), Learners and Pedagogy, pp. 34-45. London: Sage.

STEPHEN, A. (2004) Using learning outcomes: a consideration of the nature, role, application and implications for European education of employing learning outcomes at the local, national and international levels. United Kingdom Bologna Seminar, Heriot-Watt University (Edinburgh Conference Centre). Edinburgh: Scottish Executive.

STEPHENS, J. (1995) Artist or teacher? International Journal of Music Education, 25, 3-15.

TEJEDOR TEJEDOR, F. J. (1998) Los Alumnos de la Universidad de Salamanca: características y rendimiento académico. Salamanca: Ediciones de la Universidad de Salamanca.

TEJEDOR TEJEDOR, F. J. (2003) Poder explicativo de algunos determinantes del rendimiento en los estudios universitarios. Revista española de pedagogía, 61, 5-32.

TEJEDOR TEJEDOR, F. J. \& CARIDE GÓMEZ, J. A. (1988) Influencia de las variables contextuales en el rendimiento académico. Revista de educación, 287, 113-146.

TOURÓN FIGUEROA, J. (1984) Factores del rendimiento académico en la Universidad. Pamplona: Universidad de Navarra.

TOURÓN FIGUEROA, J. (1985) La predicción del rendimiento académico: procedimiento, resultados e implicaciones. Revista española de pedagogía, 43, 473-496.

WINNE, P. H. (1997) Experimenting to bootstrap self-regulated learning. Journal of Educational Psychology, 89, 397-410.

\section{CAMBRIDGE JDURNALS}

